Genij Ortopedii. 2021. Vol. 27, no. 5. P. 521-526.

Original article

https://doi.org/10.18019/1028-4427-2021-27-5-521-526

\title{
Survival analysis of the femoral component retained in isolated acetabular revision of the hip prosthesis
}

\author{
K.P. Zvereva ${ }^{\varpi}$, V.V. Ostrovskiy, D.A. Markov, A.V. Sertakova, A.N. Reshetnikov
}

Saratov Razumovsky State Medical University, Saratov, Russian Federation

Corresponding author: Kseniia P.Zvereva, ksenya.zvereva.91@mail.ru

\begin{abstract}
Introduction Isolated acetabular revision with the retention of a well-fixed and aligned femoral component is the priority treatment method in aseptic acetabular loosening. The aim of the research was to predict the survival rate of a well-fixed and aligned femoral component retained during the isolated acetabular revision surgery. Material and methods We used the survival tables and the KaplanMeier method to create the survival curves. The object of the study was the database of 44 patients (45 interventions) who underwent isolated acetabular revision surgeries with their well-fixed and aligned femoral components that was retained. The average age of the patients was 59.5 [50;69.5] years. The ratio of women to men was $25: 19$, respectively. The observation period was 1374 days. The creation of tables and graphs was carried out in Statistica 13.3 software package. Results The survival rate of the retained well-fixed and aligned femoral component in isolated acetabular revision within the period up to 4 years was high and amounted to $0.9524 \pm$ 0.03. The probability density and the hazard rates were 0.0017 and 0.00320 , respectively. Discussion The retention of a well-fixed and aligned stem in acetabular revision features high survival of the components as well as a low risk of endoprosthesis failure within 3 to 4 years. This fact confirms the need to maintain a stable and correctly oriented stem to reduce the surgical trauma, obtain good functional results and reduce rehabilitation terms. Conclusion Isolated acetabular revision in isolated aseptic cup loosening is a priority method of surgical treatment with a low risk of complications in the postoperative period.

Keywords: hip endoprosthesis, aseptic loosening, hip revision, well-fixed femoral component, survival analysis of removal stable component

For citation: Zvereva K.P., Ostrovskiy V.V., Markov D.A., Sertakova A.V., Reshetnikov A.N. Survival analysis of the femoral component retained in isolated acetabular revision of the hip prosthesis. Genij Ortopedii, 2021, vol. 27, no 5, pp. 521-526. https://doi.org/10.18019/1028-4427-202127-5-521-526
\end{abstract}

\section{INTRODUCTION}

Isolated aseptic instability of the acetabular component in the hip arthroplasty is the most common complication of arthroplasty in the long term [1-4]. According to the data of domestic and foreign literature, it may develop after 3 to 10 years. The basic causes of aseptic instability of endoprosthesis components are inflammation and activation of the RANK / RANKL / OPG system due to the debris of friction pairs in the implantation area that lead to the development of paraimplant osteolysis [5-8].

The priority method of surgical treatment is isolated acetabular revision with retension of a stable and wellaligned femoral component, characterized by low trauma, good postoperative functional results and reduction of the rehabilitation period compared to total revision [9-13].

A prerequisite for an isolated acetabular revision is the replacement of the friction pair (head-insert). At present, as part of the unification of the components of the endoprosthesis, the cone of the neck of the femoral component and implant heads of hip endoprosthesis have been standardized to a size of $12 / 14 \mathrm{~mm}$.
However, it is worth noting that in hip joint revision, orthopedists face the problem of non-standard cones of the stem, installed at an earlier date, and the lack of suitable heads. This leads to the need for extraction of a stable and well-alinged femoral component, what is always accompanied by the formation of proximal femur defects, subsequently requiring bone autoor alloplasty. It may result in complications such as a periprosthetic fracture of the femur followed by consolidation problems or fat embolism 15]. In order to solve this issue, we have developed an adapter to standardize the size of the cone of the stem neck to $12 / 14 \mathrm{~mm}$, then to replace the friction pair and maintain a stable well-alinged femoral component (RF patent for invention № 2654275 from 17.05.2018. Method of revision ip arthroplasty and device for its implementation (inventors Zvereva KP, Markov DA, Pavlenko NN, Kireev SI, Belonogov VN).

Purpose Prediction of the survival of a stable and well-aligned femoral component with a standard cervical cone size in isolated acetabular revision.

\section{MATERIAL AND METHODS}

We analyzed the survival/onset of the event of the retained stable and well-alined femoral component in isolated acetabular revisions that were performed at the traumatology and orthopedic department No. 4 of the NIITON Razumovsky Saratov State Medical University of the Ministry of Health of Russia in the period from
January 1, 2014 to December 31, 2017 due to aseptic instability of the endoprosthesis cup.

The object of research was a medical database containing information on 44 patients (45 interventions), which included

- date of the revision intervention; 
- date of the end of the study;

- censoring variable $(0-$ censored patient (the patient dropped out of the study for any reason, but at the time of withdrawal there was no implant failure; 1 uncensored patient (the patient dropped out of the study due to implant failure)).

The implant failure (final cumulative point) was considered the onset of complications such as component instability, development of peri-implant suppuration, fatigue fracture of the metal structure, dislocation of the implant head. Data censoring was right-sided (the end of the study was located to the right of the start point of the study).

Inclusion criteria were:

1) isolated instability of the acetabular component;

2) stable and correctly aligned femoral component;

3) non-infectious genesis of the disease (history, clinical data, laboratory data);

4) compensated somatic state of the patient;

5) laboratory red blood count within the range of normal values;

6) voluntary consent of the patient to surgery.

Exclusion criteria were:

1) pathology of the sciatic nerve according to electroneuromyographic research;

2) severe pathology of the knee and ankle joints (gonarthrosis and crusarthrosis in stage 3-4 according to X-rays).

The average age of the patients was 59.5 [50; 69.5] years. The ratio of women to men was $25: 19$, respectively. The follow-up period averaged $26 \pm 1.4$ months. The duration of the study was 1374 days.

The analysis of the event onset was performed using the survival/life tables method and the Kaplan-Meier method in the Statistica 13.3 software (Stat Soft, USA). To be able to use these statistical methods, the following conditions must be met [16]:

1) the moment of the beginning of the study must be clearly defined;

2) a clear understanding and definition of the outcome is necessary (in most studies, the outcome is the death of the patient, in our case the outcome is implant failure);

3) for uncensored data, the date of occurrence of the outcome must be known;

4) for censored data, the date of the patient's last contact with the investigator must be known;

5) conditions that affect survival do not change over time;

6) the number of objects in the sample should not be less than 30 .

The survival table method determines the occurrence of an event at a fixed point in time from the beginning of the study [16]. The entire study period was divided automatically by the Statistica 13.3 program into 12 equivalent periods, since the time boundaries did not play a decisive role for the study results. The first five columns contain general information about the group. Interval Start - the beginning of the study time interval. Mid Point - the middle of the investigated time interval. Interval Width - the width of the investigated time interval. Number Entering - the number of patients at the beginning of the studied time interval. Number Withdrwn - The number of censored patients who dropped out of the study. Number Exposed - the number of patients at the beginning of the study time interval minus half of the censored patients who dropped out of the study. Number Dying - the number of uncensored patients. Proportn Dead is the ratio of the number of uncensored patients to the number of patients at the beginning of the studied time interval. Proportn Survivng is the ratio of the number of censored patients to the number of patients at the beginning of the studied time interval. Cum. Prop Survivng (cumulative proportion of surviving objects or survival function) - the cumulative proportion of survivors (the probability that the patient will not develop implant failure in the studied time interval). It is calculated using the 1-Proportn Dead formula. Problty Density (probability density) - probability density of implant failure in the studied time interval. It is calculated by the formula: Cum. Prop Survivng in the studied time interval - Cum. Prop Survivng in the next time interval / Interval Width. Hazard Rate (Instant risk function or intensity function) - the intensity of failure or the function of instant risk - the probability of the implant failure in the studied time interval in a patient, when it has not yet occurred at the beginning of this interval. The indicator is also one of the most important characteristics describing the course of the disease. Std. Err. Cum. Surv is the standard error of the survival function (estimates the variability of the survival function). Std. Err. Prob. Den is the standard error of the probability density of implant failure (estimates the variability of the probability of implant failure). Std. Err. Haz. Rate is the standard error of the instantaneous risk function (estimates the variability of the instantaneous risk function). Median Life Exp (Median Life Expectancy) - the median life expectancy. Std. Err. Life Exp is the standard error of the median of the expected life span.

The Kaplan-Meier method (Kaplan-Meier multiplier estimate) estimates the probability of no outcome (in our case, implant failure) at a certain point in time from the start of the study. This probability is called "survival", and the function of dependence of survival on time is a function of survival. The survival function is the product of the survival probabilities for all previous points in time [17]. In the graphical display, uncensored patients are shown in a circle, and censored patients are represented by a cross.

The medical database containing information on 44 patients (45 interventions) was processed using Statistica 13.3 using statistical parameters: the life (survival) table method and the Kaplan-Meier method. The study was carried out after informed consent was signed by the patients and the permission of the local ethics committee of the Razumovsky Saratov State Medical University of the Ministry of Health of Russia was obtained in accordance with ethical standards developed in the Declaration of Helsinki of the World Association "Ethical principles of medical research involving human subjects", as amended in 2000. 


\section{RESULTS}

The analysis of the survival rate of the retained stable wellaligned femoral component of the hip joint endoprosthesis after isolated acetabular revision intervention began with the construction of the survival table (Table 1).

The average follow-up period for one patient was $25[17 ; 38]$ months. The time from the beginning of the study until the last patient left it was 1374 days, which were automatically divided into 12 equal time intervals. The general characteristics of the intervals are shown in columns $2-10$.

The most important statistical indicators for assessing survival are the survival function (Cum. Prop Survivng), the probability density (Problty Density), and the instantaneous risk function (Hazard Rate).
The survival function (Cum. Prop Survivng) (the probability that the patient will not develop endoprosthesis failure in the studied time interval) in 1 time interval was 1.0. Further on, a gradual decrease in the value of the indicator was noted in connection with the appearance of censored patients and a decrease in the number of observed patients. The cumulative endpoint and the appearance of uncensored patients were noted in time intervals 2 and 3. By the end of the study, the survival function was 0.417 . This means that the probability of implant failure by 4 years after the isolated acetabular revision was $41.7 \%$. A graphical representation of the survival function is shown in Figure 1.

Table1

Life table

\begin{tabular}{|c|c|c|c|c|c|c|c|c|c|c|}
\hline & \multicolumn{9}{|c|}{ Life Table (survival) Log-Likelihood for data: -13,8988 } \\
\cline { 2 - 11 } & 1 & 2 & 3 & 4 & 5 & 6 & 7 & 8 & 9 \\
\cline { 2 - 11 } & $\begin{array}{c}\text { Interval } \\
\text { Start }\end{array}$ & Mid Point & $\begin{array}{c}\text { Interval } \\
\text { Width }\end{array}$ & $\begin{array}{c}\text { Number } \\
\text { Entering }\end{array}$ & $\begin{array}{c}\text { Number } \\
\text { Withdrwn }\end{array}$ & $\begin{array}{c}\text { Number } \\
\text { Exposed }\end{array}$ & $\begin{array}{c}\text { Number } \\
\text { Dying }\end{array}$ & $\begin{array}{c}\text { Proportn } \\
\text { Dead }\end{array}$ & $\begin{array}{c}\text { Proportn } \\
\text { Survivng }\end{array}$ \\
\hline Intno. 1 & 0.00 & 62.45 & 124.91 & 45 & 3 & 43.50 & 0 & 0.011 & 0.989 \\
\hline Intno. 2 & 124.91 & 187.36 & 124.91 & 42 & 3 & 40.50 & 1 & 0.025 & 0.975 \\
\hline Intno. 3 & 249.82 & 312.27 & 124.91 & 38 & 9 & 33.50 & 1 & 0.030 & 0.970 \\
\hline Intno. 4 & 374.73 & 437.18 & 124.91 & 28 & 2 & 27.00 & 0 & 0.019 & 0.981 \\
\hline Intno. 5 & 499.64 & 562.09 & 124.91 & 26 & 4 & 24.00 & 0 & 0.021 & 0.979 \\
\hline Intno. 6 & 624.55 & 687.00 & 124.91 & 22 & 6 & 19.00 & 0 & 0.026 & 0.974 \\
\hline Intno. 7 & 749.45 & 811.91 & 124.91 & 16 & 3 & 14.50 & 0 & 0.034 & 0.966 \\
\hline Intno. 8 & 874.36 & 936.82 & 124.91 & 13 & 3 & 11.50 & 0 & 0.043 & 0.957 \\
\hline Intno. 9 & 999.27 & 1061.73 & 124.91 & 10 & 6 & 7.00 & 0 & 0.071 & 0.929 \\
\hline Intno. 10 & 1124.18 & 1186.64 & 124.91 & 4 & 2 & 3.00 & 0 & 0.167 & 0.833 \\
\hline Intno. 11 & 1249.09 & 1311.55 & 124.91 & 2 & 1 & 1.50 & 0 & 0.333 & 0.667 \\
\hline Intno. 12 & 1374.00 & & & 1 & 1 & 0.50 & 0 & 1.000 & 0.000 \\
\hline
\end{tabular}

\begin{tabular}{|c|c|c|c|c|c|c|c|c|}
\hline \multirow{2}{*}{ Interval } & \multicolumn{7}{|c|}{ Life Table (survival) Log-Likelihood for data: -13,8988 } \\
\cline { 2 - 9 } & 10 & 11 & 12 & 13 & 14 & 15 & 16 & 17 \\
\cline { 2 - 10 } & $\begin{array}{c}\text { Cum.Prop } \\
\text { Survivng }\end{array}$ & $\begin{array}{c}\text { Problty } \\
\text { Density }\end{array}$ & $\begin{array}{c}\text { Hazard } \\
\text { Rate }\end{array}$ & $\begin{array}{c}\text { Std.Err. } \\
\text { Cum.Surv }\end{array}$ & $\begin{array}{c}\text { Std.Err. } \\
\text { Prob.Den }\end{array}$ & $\begin{array}{c}\text { Std.Err. } \\
\text { Haz.Rate }\end{array}$ & $\begin{array}{c}\text { Median } \\
\text { Life Exp }\end{array}$ & $\begin{array}{c}\text { Std.Err. } \\
\text { Life Exp }\end{array}$ \\
\hline Intno. 1 & 1.000 & 0.0001 & 0.00009 & 0.000 & 0.00013 & 0.00013 & 1324.26 & 45.42 \\
\hline Intno. 2 & 0.989 & 0.0002 & 0.00020 & 0.016 & 0.00019 & 0.00020 & 1202.80 & 46.53 \\
\hline Intno. 3 & 0.964 & 0.0002 & 0.00024 & 0.029 & 0.00023 & 0.00024 & 1085.20 & 49.90 \\
\hline Intno. 4 & 0.935 & 0.0001 & 0.00015 & 0.040 & 0.00019 & 0.00021 & 968.91 & 53.92 \\
\hline Intno. 5 & 0.918 & 0.0002 & 0.00017 & 0.046 & 0.00021 & 0.00024 & 849.19 & 56.13 \\
\hline Intno. 6 & 0.899 & 0.0002 & 0.00021 & 0.052 & 0.00026 & 0.00030 & 730.01 & 61.77 \\
\hline Intno. 7 & 0.875 & 0.0002 & 0.00028 & 0.061 & 0.00034 & 0.00040 & 612.19 & 68.85 \\
\hline Intno. 8 & 0.845 & 0.0003 & 0.00036 & 0.072 & 0.00041 & 0.00050 & 496.32 & 74.65 \\
\hline Intno. 9 & 0.808 & 0.0005 & 0.00059 & 0.086 & 0.00063 & 0.00084 & 374.73 & 0.00 \\
\hline Intno. 10 & 0.751 & 0.0010 & 0.00146 & 0.112 & 0.00130 & 0.00205 & 249.82 & 0.00 \\
\hline Intno. 11 & 0.625 & 0.0017 & 0.00320 & 0.186 & 0.00199 & 0.00444 & 124.91 & 0.00 \\
\hline Intno. 12 & 0.417 & & & 0.271 & & & & \\
\hline
\end{tabular}

Note: Interval - study time interval; Interval Start - the beginning of the study time interval; Mid Point - the middle of the investigated time interval; Interval Width - the width of the investigated time interval; Number Entering - the number of patients at the beginning of the studied time interval; Number Withdrwn - the number of censored patients; Number Exposed - the number of patients at the beginning of the study time interval minus half of the censored patients who dropped out of the study; Number Dying - the number of uncensored patients; Proportn Dead - the proportion of uncensored patients; Proportion Surviving - the proportion of censored patients; Cum. Prop Survivng - the cumulative proportion of survivors; Problty Density - probability density; Hazard Rate - instant risk function; Std. Err. Cum. Surv is the standard error of the survival function; Std. Err. Prob. Den is the standard error of the probability density of the implant failure; Std. Err. Haz. Rate is the standard error of the instant risk function; Median Life Exp - the median of the expected life span; Std. Err. Life Exp is the standard error of the median of the expected life span. 


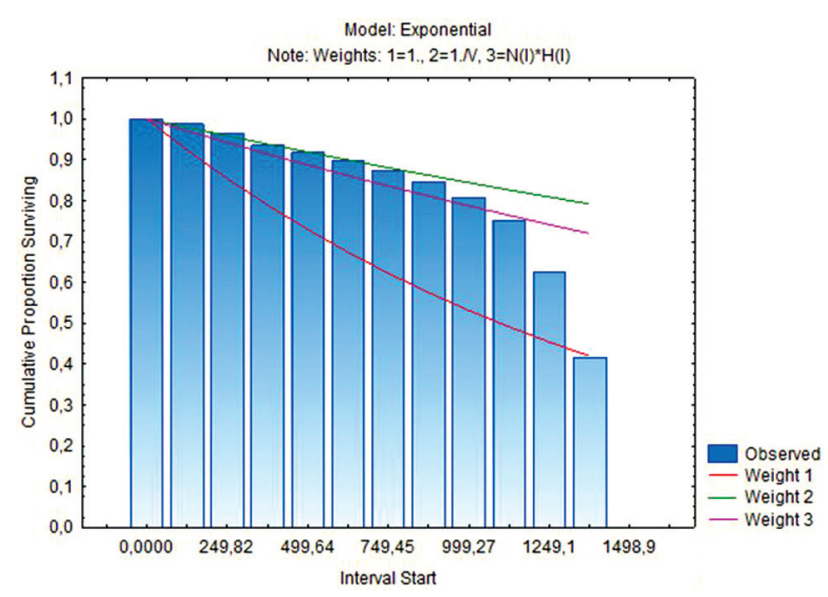

Fig. 1 Function of survival. Note: Model Exponentialexponential distribution; Cumulative Proportion Survivingthe cumulative proportion of survivors; Interval Start - the beginning of the study time interval; Observed - the subject of observation; Weight 1 - least squares method; Weight 2, 3 weighted least squares method

The probability density of implant failure (Problty Density - the probability density of the endoprosthesis failure in the studied time interval) was 0.0001 in the first time interval. In time intervals 2 and 3, due to the appearance of uncensored patients, the probability density of the endoprosthesis failure increased to 0.0002 . Subsequently, due to a decrease in the survival function, an increase in the indicator was noted up to 0.0017 by the end of the study. This means that by 4 years after the isolated acetabular revision, the probability of implant failure was 17: 10000 (Fig. 2).

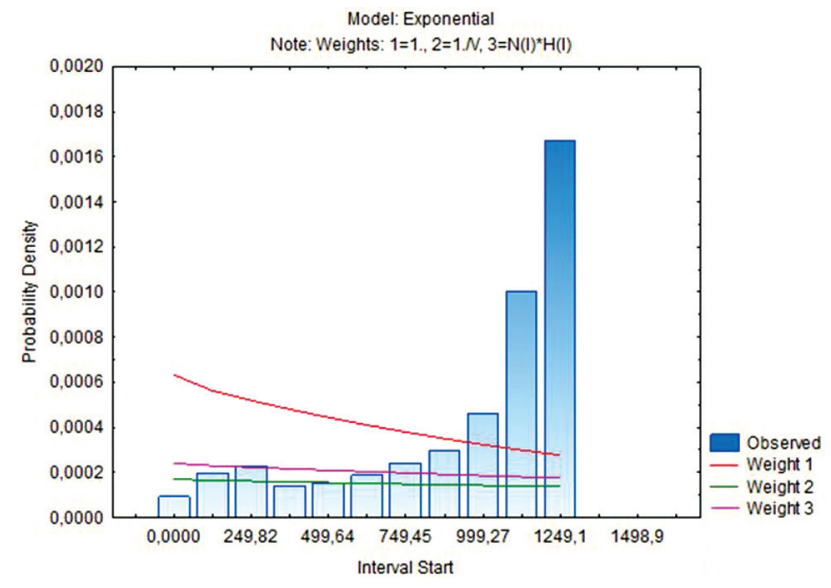

Fig. 2 Probability of density of implant failure. Note: Model Exponential - exponential distribution; Probability density probability density; Interval Start - the beginning of the study time interval; Observed - the subject of observation; Weight $1-$ least squares method; Weight 2,3-weighted least squares method

The instantaneous risk function (Hazard Rate - the probability of implant failure in the studied time interval in a patient, when it has not yet occurred at the beginning of this interval) is minimal within 3 years and reaches 0.00059 by 1124 days from the start of the study. Then there is a slight increase in the function of instantaneous risk, which is probably associated with long-term functioning of the implant. By the end of the study, the value of the indicator was 0.00320 . That means that by 4 years after the isolated acetabular revision, the risk of implant failure was 320: 100,000 (Fig. 3).

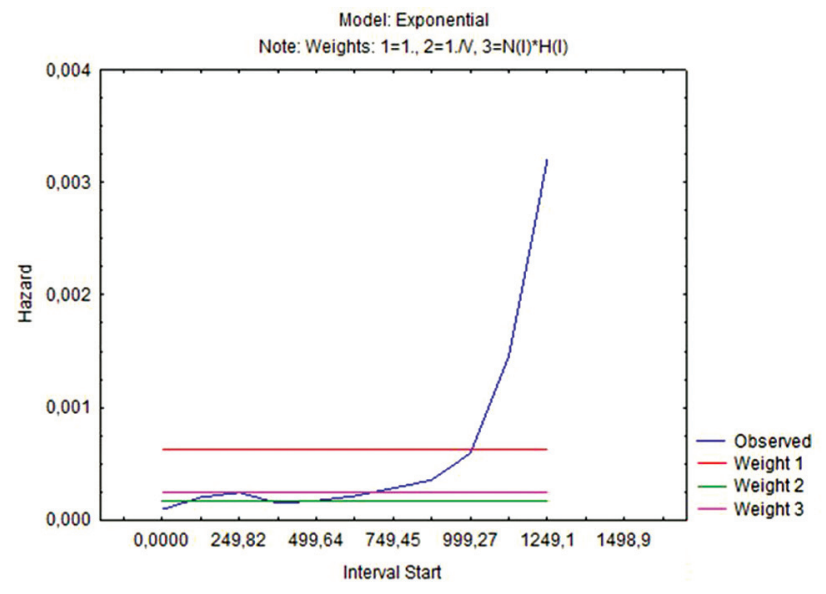

Fig. 3 Function of instantaneous risk. Note: Model Exponentialexponential distribution; Hazard - instant risk function; Interval Start - the beginning of the study time interval; Observed the subject of observation; Weight 1 - least squares method; Weight 2, 3- weighted least squares method

It can be noted that the estimates of the instantaneous risk function obtained by different methods (the method of least and two methods of weighted least squares, the lines Weight $1,2,3$, respectively) have the form of a constant ( $\mathrm{f}(\mathrm{x})=\mathrm{C}, \mathrm{C}=$ const.), what is typical for life expectancy in the presence of a chronic disease.

At the beginning of the study, the survival rate of the components according to the Kaplan-Meier method was $1.0(100 \%)$. Subsequently, there was a decrease in the multiplier score to $0.9524 \pm 0.03(95.24 \pm 3 \%)$, which was due to the appearance of uncensored patients. The survival function is shown in Figure 4.

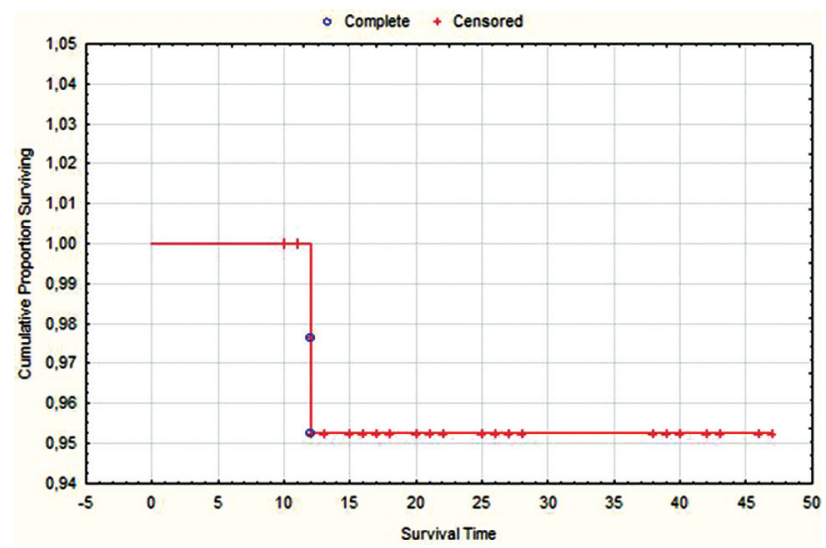

Fig. 4 Survival function. Note: Cumulative Proportion Surviving - the cumulative proportion of survivors; Survival time - lifetime (months); Complete - uncensored patients; Censored - censored patients

\section{DISCUSSION}

Isolated acetabular revision is a priority method of surgical treatment of patients with aseptic instability of the acetabular component and a stable wellaligned femoral component [18-20]. This method is characterized by good functional results and shortens the terms of rehabilitation treatment. Given the advanced age and severe comorbidities of patients requiring revision intervention, reduction of the operation invasiveness 
is one of the fundamental points [21, 22]. However, at present, there is a need for extraction and reinstallation of a stable stem of the endoprosthesis in case of a nonstandard neck cone and the impossibility of replacing the head-insert friction pair. This is accompanied by a significant increase in the invasiveness of the intervention and surgical blood loss, the formation of bone defects needing auto- or alloplasty, various types of osteotomies of the femur, the occurrence of its fractures, fat embolism, and deterioration of functional postoperative results [2330]. To solve this problem, we have developed an adapter that enables to standardize the size of the stem neck cone to $12 / 14 \mathrm{~mm}$, replace the friction pair and retain a stable well-aligned oriented femoral component.

According to the data obtained in this study, the survival rate of the retained stable and well-aligned femoral component with a standard size of the cervical cone within 4 years from the moment of acetabular revision intervention is at a high level and reaches $0.9524 \pm 0.03$. The likelihood of implant failure is minimal during the first 3 years from the date of surgical treatment. In the following year, there is a slight increase in the indicator to 0.0017 . The instant risk function was also recorded at a low level throughout the study period, amounting to 0.00320 at the end of the study.

Summarizing all the above, it can be stated that the high survival rate of the implant components and the low risk of complications in the long-term period after acetabular revision confirm the need to retain a stable and well-alinged stem of the endoprosthesis to reduce the trauma of the operation, obtain good functional results and shorten the rehabilitation period.

\section{CONCLUSION}

1. The function of survival, studied using survival tables and the Kaplan-Meier method, was characterized by high rates in the entire study period and reached $0.417 \pm 0.271$ and $0.9524 \pm 0.03$, respectively.

2. The instantaneous risk function was recorded at a

low level and reached 0.00320 by 4 years from the start of the study.

3. Preservation of a stable and well aligned femoral component in acetabular revision intervention is characterized by high survival rate of components and low risk of implant failure within 3 to 4 years.

\section{REFERENCES}

1. Nikolaev I.A. Tekhnologii zameshcheniia kostnykh defektov pri revizii vertluzhnogo komponenta tazobedrennogo sustava. Avtoref. diss. ... kand. med. nauk [Technologies for replacing bone defects during revision of the hip acetabular component. Cand. med. sci. diss. abstr.]. M., 2015, 24 p. (in Russian)

2. Shesternia N.A., Lazarev A.F., Ivannikov S.V., Zharova T.A., Solod E.I., Abdul A.M. Endoprotezirovanie tazobedrennogo sustava: nestabilnost vertluzhnogo komponenta [Arthroplasty of the hip: acetabular component instability]. Kafedra Travmatologii i Ortopedii, 2016 , no. 3 (19), pp. 39-44. (in Russian)

3. Waewsawangwong W., Ruchiwit P., Huddleston J.I., Goodman S.B. Hip arthroplasty for treatment of advanced osteonecrosis: comprehensive review of implant options, outcomes and complications. Orthop. Res. Rev., 2016, vol. 8, pp. 13-29. DOI: 10.2147/ORR.S35547.

4. Kumar A., Soni M., Patel J., Rawat S. Aseptic loosening of isolated cemented acetabular cup. International Journal of Advanced Research, 2016 , vol. 4, no. 5, pp. 1320-1322. DOI: 10.21474/IJAR01/422.

5. Hallab N.J., Jacobs J.J. Biologic effects of implant debris. Bull. NYU Hosp. Jt. Dis., 2009, vol. 67, no. 2, pp. $182-188$.

6. Rozhnova O.M., Prokhorenko V.M., Sadovoi M.A., Samokhin A.G., Ageeva T.A. Patogeneticheskie faktory formirovaniia asepticheskoi nestabilnosti endoprotezov sustavov (obzor literatury) [Pathogenetic factors of forming aseptic instability of joint implants (Review of the literature)]. Sibirskii Nauchnyi Meditsinskii Zhurnal, 2015, vol. 35, no. 5, pp. 85-88. (in Russian)

7. Riabova M.N. Asepticheskaia nestabilnost atsetabuliarnogo komponenta pri bestsementnom endoprotezirovanii tazobedrennogo sustava [Aseptic instability of acetabular component in cementless arthroplasty of the hip]. Nauka Molodykh, 2016, no. 4, pp. 117-125. (in Russian)

8. Hartmann E.S., Köhler M.I., Huber F., Redeker J.I., Schmitt B., Schmitt-Sody M., Summer B., Fottner A., Jansson V., Mayer-Wagner S. Factors regulating bone remodeling processes in aseptic implant loosening. J. Orthop. Res., 2017, vol. 35, no. 2, pp. 248-257. DOI: 10.1002/jor.23274.

9. Gankina M.S. Vikoristannia metodu tablits vizhivannia v doslidzhenni stanu sanatoriiu Ukraïni [Using the method of survival tables in the study of the state of the sanatorium of Ukraine]. Biznesinform, 2016, no. 11, pp. 128-133. (in Ukrainian) Available at: http://nbuv.gov.ua/UJRN/binf_2016_11_23.

10. Kim Y.H. Acetabular Cup Revision. Hip Pelvis, 2017, vol. 29, no. 3, pp. 155-158. DOI: 10.5371/hp.2017.29.3.155.

11. Markov D.A., Zvereva K.P., Sertakova A.V., Belonogov V.N., Troshkin A.Iu. Khirurgicheskoe lechenie izolirovannoi asepticheskoi nestabilnosti vertluzhnogo komponenta u patsientov so stabilnym femoralnym komponentom [Surgical treatment of isolated aseptic instability of an acetabular component in patients with a stable femoral component]. Vestnik Rossiiskoi Akademii Meditsinskikh Nauk, 2018, vol. 73, no. 3, pp. 164-171. (in Russian)

12. Kaku N., Tabata T., Tagomori H., Tsumura H. Isolated acetabular revision with femoral stem retention after bipolar hip arthroplasty. Arch. Orthop. Trauma Surg., 2017, vol. 137, no. 3, pp. 425-430. DOI: 10.1007/s00402-017-2633-y.

13. Wu K.T., Wang J.W., Lu Y.D., Yen S.H., Lee M.S. Isolated revision of the acetabular component using alumina-on-alumina bearings without a metal sleeve: A preliminary study. J. Orthop. Surg. (Hong Kong), 2017, vol. 25, no. 2, 2309499017721041. DOI: 10.1177/2309499017721041.

14. De Thomasson E., Conso C., Mazel C. A well-fixed femoral stem facing a failed acetabular component: to exchange or not? A 5- to 15-year follow-up study. Orthop. Traumatol. Surg. Res., 2012, vol. 98, no. 1, pp. 24-29. DOI: 10.1016/j.otsr.2011.08.014.

15. Laffosse J.M. Removal of well-fixed fixed femoral stems. Orthop. Traumatol. Surg. Res., 2016, vol. 102, no. 1 Suppl., pp. S177-S187. DOI: 10.1016/j. otsr.2015.06.029.

16. Sharashova E.E., Kholmatova K.K., Gorbatova M.A., Grzhibovskii A.M. Primenenie analiza vyzhivaemosti v zdravookhranenii s ispolzovaniem paketa statisticheskikh programm SPSS [Application of survival analysis in healthcare using the SPSS statistical software package]. Nauka $i$ Zdravookhranenie, 2017, no. 5, pp. 5-28. (in Russian)

17. Slinin A.S., Bydanov O.I., Karachunskii A.I. Analiz vyzhivaemosti i veroiatnosti vozniknoveniia otdelnykh sobytii u patsientov s ostrym leikozom [Analysis of survival and the likelihood of individual events in patients with acute leukemia]. Voprosy Gematologii/Onkologii $i$ Immunopatologii $v$ Pediatrii, 2016, vol. 15, no. 3, pp. 34-39. (in Russian)

18. Chen X.D., Waddell J.P., Morton J., Schemitsch E.H. Isolated acetabular revision after total hip arthroplasty: results at 5-9 years of follow-up. Int. Orthop., 2005, vol. 29, no. 5, pp. 277-280. DOI: 10.1007/s00264-005-0674-2.

19. Kim Y.H., Park J.W., Kim J.S. Isolated revision of an acetabular component to a ceramic-on-ceramic bearing in patients under 50 years of age. Bone Joint J., 2015, vol. 97-B, no. 9, pp. 1197-1203. DOI: 10.1302/0301-620X.97B9.35748.

20. Marongiu G., Podda D., Mastio M., Capone A. Long-term results of isolated acetabular revisions with reinforcement rings: a 10- to 15 -year follow-up. Hip Int., 2019, vol. 29, no. 4, pp. 385-392. DOI: 10.1177/1120700018802750.

21. Greiner J.J., Callaghan J.J., Bedard N.A., Liu S.S., Gao Y., Goetz D.D. Fixation and wear with contemporary acetabular components and cross-linked polyethylene at 10-years in patients aged 50 and under. J. Arthroplasty, 2015, vol. 30, no. 9, pp. 1577-1585. DOI: 10.1016/j.arth.2015.05.011. 
22. Piolanti N., Andreani L., Parchi P.D., Bonicoli E., Niccolai F., Lisanti M. Clinical and radiological results over the medium term of isolated acetabular revision. ScientificWorld Journal, 2014, vol. 2014, 148592. DOI: 10.1155/2014/148592. Available at: https://www.ncbi.nlm.nih.gov/pmc/articles/

23. Fukui K., Kaneuji A., Sugimori T., Ichiseki T., Kitamura K., Matsumoto T. Should the well-fixed, uncemented femoral components be revised during isolated acetabular revision? Arch. Orthop. Trauma Surg., 2011, vol. 131, no. 4, pp. 481-485. DOI: 10.1007/s00402-010-1152-x.

24. Megas P., Georgiou C.S., Panagopoulos A., Kouzelis A. Removal of well-fixed components in femoral revision arthroplasty with controlled segmentation of the proximal femur. J. Orthop. Surg. Res., 2014, vol. 9, pp. 137. DOI: 10.1186/s13018-014-0137-9.

25. Kerboull L. Selecting the surgical approach for revision total hip arthroplasty. Orthop. Traumatol. Surg. Res., 2015, vol. 101, no. 1 Suppl., pp. S171-S178. DOI: 10.1016/j.otsr.2014.07.031.

26. Fink B., Oremek D. The Transfemoral Approach for Removal of Well-Fixed Femoral Stems in 2-Stage Septic Hip Revision. J. Arthroplasty, 2016, vol. 31, no. 5, pp. 1065-1071. DOI: 10.1016/j.arth.2015.11.008.

27. Nabors E.D., Liebelt R., Mattingly D.A., Bierbaum B.E. Removal and reinsertion of cemented femoral components during acetabular revision. J. Arthroplasty, 1996, vol. 11, no. 2, pp. 146-152. DOI: 10.1016/s0883-5403(05)80008-7.

28. Paprosky W.G., Weeden S.H., Bowling J.W. Jr. Component removal in revision total hip arthroplasty. Clin. Orthop. Relat. Res., 2001, no. 393, pp. 181193. DOI: 10.1097/00003086-200112000-00021.

29. Fink B. The transfemoral approach for controlled removal of well-fixed femoral stems in hip revision surgery. J. Clin. Orthop. Trauma, 2020, vol. 11, no. 1, pp. 33-37. DOI: 10.1016/j.jcot.2019.11.001.

30. Puget J. Extraction des tiges fémorales difficilement extirpables [Extraction of hard to remove femoral stems]. Rev. Chir. Orthop. Repar. Appar. Mot., 2007, vol. 93, no. 6 Suppl., pp. 145-160. (in French)

The article was submitted 16.03.2021; approved after reviewing 09.08.2021; accepted for publication 23.08.2021.

\section{Information about authors:}

1. Kseniia P. Zvereva - M.D., ksenya.zvereva.91@mail.ru;

2. Vladimir V. Ostrovskiy - Doctor of Medical Sciences;

3. Dmitrii A. Markov - Candidate of Medical Sciences;

4. Anastasia V. Sertakova - Candidate of Medical Sciences;

5. Andrei N. Reshetnikov - Doctor of Medical Sciences.

Conflict of interests The authors confirmed that they have no conflicts of interest to disclose. 